\title{
Lessons from historical monetary unions - is the European monetary union making the same mistakes?
}

\author{
John Ryan ${ }^{1}$ • John Loughlin ${ }^{2}$
}

\begin{abstract}
This article examines three historical monetary unions: the Latin Monetary Union (LMU), the Scandinavian Monetary Union (SMU), and the Austro-Hungarian Monetary Union (AHMU) in an attempt to derive possible lessons for the European Monetary Union (EMU). The term 'monetary union' can be defined either narrowly or broadly depending on how closely it conforms to Mundell's notion of 'Optimal Currency Area'. After examining each of the historical monetary unions from this perspective, the article concludes that none of them ever truly conformed to Mundell's concept, nor does the EMU. Nevertheless, the article argues that some lessons may be learned from these historical experiences. First, it is necessary that there exist robust institutions such as a common central bank and a unified fiscal policy in order to withstand external shocks. The three early unions could not withstand the shock of WWI. Another important lesson is that continuing national rivalries can undermine any monetary union.
\end{abstract}

Keywords Latin monetary union · Scandinavian monetary union · Austro-Hungarian monetary union · European monetary union · Eurozone crisis · European Central Bank

JEL classification $\mathrm{E} 42 \cdot \mathrm{E} 50 \cdot \mathrm{E} 52 \cdot \mathrm{F} 02 \cdot \mathrm{F} 50$

\section{Introduction}

This article examines three historical monetary unions: the Latin Monetary Union (LMU), the Scandinavian Monetary Union (SMU), and the Austro-Hungarian Monetary Union (AHMU) in an attempt to derive possible lessons for the current European

John Ryan

j.t.ryan@1se.ac.uk

1 LSE IDEAS, London School of Economics and Political Science, London, UK

2 St Mary's University Twickenham, Twickenham, UK 
Monetary Union (EMU). The three cases were chosen because they are all in Europe and, at least in some respects, may be seen as pre-cursors of the EMU (Loughlin and Ryan 2014).

A monetary union is one where there is a single fiat currency with a single monetary authority (a central bank). It also has a single interest and exchange rate, and a single legal entity responsible for issuing that currency across a geographic area. This combination of features required for a true monetary union suggests that many previous monetary unions, including the LMU and SMU were not monetary unions as such, while the AHMU was and the Eurozone is. The SMU, at least before 1901, was similar to the LMU in being largely a common standardization of weights and measures, although after 1901 it came closer to being a monetary union, even though the currencies of Sweden, Denmark, and Norway still existed in distinct forms and there was no common interest rate.

The term 'monetary union', however, is used in a somewhat looser way in this article to refer to the LMU, SMU, AHMU, and the Eurozone, with the appropriate addition of caveats to indicate the diversity of arrangements grouped under this heading. Special attention is paid, in particular, to the importance of economic and political integration in the success and failure of historical monetary unions, with the goal of shedding light on the fraught question of whether sustained successful monetary union is possible without high levels of economic convergence in the common currency area and indeed fiscal and banking union. The article also discusses the political and institutional aspects and whether some kind of federal set of arrangements is necessary in order to sustain monetary union successfully. Focus on the EMU is not without interest, not least because these earlier failed experiments in monetary union helped to shape the modern EMU and Eurozone (Vanthoor 1996).

The article discusses the formation and progression of the EMU both institutionally and politically. Finally, it will draw some lessons from the case studies relevant to the Eurozone Crisis. Although there is a vast historical gulf separating these latenineteenth-century monetary unions from the present, they provide 'food for thought' for policy makers and commentators attempting to think through the complications facing the Eurozone (Donovan et al. 2010 and Deo et al. 2011).

\section{The Latin monetary union (LMU)}

The LMU possesses a special place in any study of monetary unions because of its importance in the history of European integration and as a source of inspiration for subsequent monetary unions. Of course, it must be remembered that the Monetary Convention's (1865) LMU between France, Italy, Belgium, and Switzerland did not create a monetary union as such, but instead represented a relatively narrow coinage agreement. While the treaty described the intention of "forming between them [i.e., the member states] a monetary union", its focus was on the "uniformity of weights, measures, and money". The LMU thus represented a standardisation of specie, which can be thought of as a fixed exchange rate between gold and silver. At the time, debate raged about whether it was advisable to adopt a gold standard system, like the British, or a bimetallic or double standard of gold and silver (Bordo 1992). 
The LMU was originally envisaged as a bimetallic agreement, in line with French preference towards bimetallism, with a set exchange rate between gold and silver of 15.5:1. Despite this, however, the LMU eventually transitioned into an effective gold standard in 1878 with a fixed exchange rate and silver being redeemable for gold. Interestingly, in the lead up to the creation of the LMU there were visionary proposals for creating a much broader international currency, which might have included the United Kingdom, Germany, and even the United States. The French economist and politician Félix Esquirou de Parieu envisaged such a union as the first step in a process of European (even global) integration, which he hoped would culminate in the creation of a full common currency, and, as he envisaged somewhat precociously, a "European Union" directed by a "European Commission" (Einaudi 2001).

Assessing the success of the LMU in the late nineteenth and early twentieth centuries is difficult. The last few decades of the LMU were extremely turbulent and witnessed a number of convulsions. As such, the failure of the LMU was a long time coming, but the union witnessed a decline from the 1870s onwards, in light of difficulties connected to the debasement of silver and fluctuations between the values of gold and silver. These difficulties were, in part, based upon a decision by Giacomo Antonelli, the administrator of the Papal Treasury, a man sometimes called by his contemporaries the "Italian Richelieu", to engage in an extensive coinage of debased silver, which was widely circulated throughout the LMU. Eventually, Swiss and French bankers rejected these coins. Despite this, the decreased value of silver made it profitable to exchange silver for gold at the set standard of 15.5: 1, and from 1873 onwards the LMU was forced to limit free conversion of silver. The final nail in the coffin of the LMU was the Great War, although the LMU officially operated until 1927.

The Swiss Bank UBS has produced a report on the history of currency unions which concluded that the "Latin Monetary Union was no monetary union in the modern sense of the word, and it offers little guidance to the Euro" (Deo et al. 2011). In a certain sense, this is true. The LMU is truly vastly different from the current arrangements witnessed in the Eurozone. Despite this, however, some useful insights that can be gleaned. The major lessons of the LMU are two-fold. First of all, the negotiations leading to the adoption of the LMU point to the difficulty of creating (and maintaining) a monetary union in light of national interests. Then, as is the case now, there was scepticism in the United Kingdom and, to a lesser degree, Germany, about the efficacy of a Europeanwide monetary union. Interestingly, a "little Englander" and anti-European press was influential in reducing any British hopes of entering into an international currency union. Similar nationalist pressures existed in Germany, and served to scupper involvement in the LMU, which incidentally was termed a Latin Monetary Union by a British press wishing to emphasise the inadvisability of Anglo-German participation. Remembering the importance of national sentiment is particularly important today as the Eurozone crisis showed resentments build both in debtor and creditor nations.

Second, the LMU can be seen as illustrating the danger of insufficient coordination of member states within a monetary union. The LMU, as a rather loose programme for standardising specie exchange rates, provided far too much scope for national power and independence in the issuing of coinage. This paved the way for the subsequent introduction of debased silver, which helped to bring the LMU to its end. Insufficient centralisation and a lack of institutional safeguards allowed national political actors to pursue their own economic interests to the detriment of the LMU's collective interests. 
What was lacking in LMU was a set of institutions such as a central bank, a sovereign entity capable of determining interest rates, and a system of fiscal transfers in cases of asymmetrical shocks. In that period of history, it was inconceivable, at least in the countries of southern Europe that formed the core of the LMU, that such institutions could be created given the overriding concept of national sovereignty that was then at its height.

\section{The Scandinavian monetary union (SMU)}

The SMU, which has been described by de Cecco as "the most successful of all European currency unions", was partially inspired by the LMU, and was deeply tied to the rise of a political Scandinavism (De Cecco 1992), It is worth mentioning again that the SMU did not represent a proper monetary union, as that term is often used today. Moreover, it is essential to delineate two discrete "phases" of the SMU, with different characteristics. Between 1875 and 1901 (Phase I), the SMU was somewhat similar to the LMU in being largely a common standardisation of weights and measures. The year 1901, however, marked a turning point, and between 1901 and 1905 (Phase II), the union came much closer to being a monetary union in the proper sense of the word. Under Phase II, the SMU ceased being a mere standardisation of specie, but instead became a fiat currency union, although one which was based upon specie. Under this system currency notes from the SMU member states circulated freely, as long as they could be converted to specie. Despite this, however, the currencies of Sweden, Denmark, and Norway still existed in distinct form and there was no common interest rate among the member states.

The SMU originally included Denmark and Sweden in 1873, and later, in 1875, included Norway, which, although in union with Sweden at that point, had full internal autonomy. The SMU was different from the LMU, however, in that it was not bimetallic, but instead rested upon the gold standard. Under the terms of the original union, the coinage was required to be of identical weight and composition. This shifted, however, as currency came to be included under the terms of SMU in 1901, and the three central banks of the member states agreed to allow the drawing of drafts on each other at par. Under the criteria of what constitutes an Optimal Currency Area (OCA), the SMU must be seen as somewhat problematic. In part, this may have been because of a lost opportunity in free trade, due to the failure to increase intra-Scandinavian trade during this same period, which would have inevitably increased economic symmetry. Whether this would have happened eventually is unknown as the SMU, like the LMU, foundered as a result of the impact of the First World War.

Perhaps, there are, once again, two major lessons to be drawn from the experience of the SMU. The conditions were actually quite propitious in the Scandinavian countries as they share similar languages and cultures and even in the nineteenth century, already imitated each other's policy approaches. There were, however - and this is the first lesson - great economic disparities across the different countries. This points to the problem of the creation of a monetary union without sufficient economic convergence among its member states. The SMU, therefore, according to Bergman, never truly qualified as an OCA, because of this lack of economic convergence. The second lesson is the need for a common framework of economic structures and fiscal institutions for a 
currency union to be successful, including, at the bare minimum the reduction of trade barriers, in part to align member states' economies with one another. There was no central bank, no sovereign entity setting interest rates and no system of fiscal transfers to respond to asymmetrical shocks. A true currency union was almost achieved in 1894 when the Norwegian and Swedish central banks agreed to accept each other's bank notes at par. Denmark joined this union in 1901. However, no single bank note emerged and the three countries each controlled their own money supplies (Deo et al. 2011).

Despite the features they held in common, monetary union proved difficult because, in practice, nationalist sentiment was also high with rivalries between the three countries. To illustrate this further, Norway finally broke the union with Sweden in 1905. Following this the exchange between the three central banks ceased. This meant that the union became more of a fixed exchange rate regime with notes and coins circulating freely within the three countries (Deo et al. 2011).

\section{The Austro-Hungarian monetary union (AHMU)}

The AHMU has largely avoided the attention of historians, and is often not classified as a "monetary union" per se, but instead as a dynastic agglomeration sharing a common currency. This, however, is not entirely fair, and in some regards the AHMU more closely approximates a true monetary union in the modern sense of the term, than either the LMU or the SMU. The AHMU was created through an agreement known as the 1867 Compromise between Austria and Hungary, but in the words of historian Marc Flandreau, it is important to remember that the "Austro-Hungarian union was not the result of a monetary marriage but the by-product of a fiscal divorce" (Flandreau 2006). The 1867 Compromise at its core ensured that Austria and Hungary shared a common currency, although they remained fiscally sovereign, independent entities. The AHMU offers, therefore, some interesting lessons and insights into the operation of monetary unions, especially in relation to the matter of political economy.

Under the AHMU, Austria and Hungary agreed to share a common market, trade policy, legal system, army, foreign policy, and monarch (with the Emperor of Austria serving as the King of Hungary). Each nation, however, would have its own national parliament, government, and budget. In terms of monetary policy more specifically, it was decided that the currency of the Austrian National Bank (ANB) would be legal tender. In addition, the inconvertible notes of the ANB would be under the joint guarantee of both governments, and Hungarians agreed not to create a bank of issue that would be in competition with the ANB. The result was a "de facto monetary union", with a number of devolved functions left in each national government, including most fiscal issues. One interesting aspect of the AHMU was the ability of the much smaller Hungary to exert influence over Austria in monetary bargaining, largely through the threat of secession.

As Flandreau explained it: Consider a monetary union comprising a "large" (Austria) and a "small" (Hungary) country. The common central bank delivers a range of services that are valuable to both parts, but not equally. The exact mix of services produced depends on the division of power. If power is proportional to size, the small country has very little control over common decisions. It is bound by the discipline of the union without being able to influence decision-making in a way that would address 
its own specific interests. Co-operation (that is, participation in the union) is suboptimal and the small country prefers to quit. Sustained co-operation requires that the large country accepts a decision-making process in which the small country receives a greater voting share than size alone would predict. Thus smaller "nations" influence monetary unions disproportionately (Flandreau 2006).

According to Flandreau's analysis, in a two-party monetary union, especially one with low barriers to exit, there will be a tendency for the smaller member state to exert an undue amount of influence over the workings of the union, through the threat of exit. This certainly appears to have been the case under the AHMU, and Flandreau believes that the result of such bargaining was that the monetary union was "quite profitable to Hungarians". In 1878, the ANB was renamed the Austro-Hungarian National Bank, and through this the new bank became a truly "federal institution".

Like the LMU and the SMU, the AHMU disappeared under the impact of the First World War, for a complex set of reasons, including the increased pressures placed upon the broader economic scene by the strains of the war. The main lesson of the AHMU, however, is about the nature of institutional structures. Two concepts are useful in thinking about this: (1) the first concept is Albert Hirschman's notion of "Exit, Voice, and Loyalty" (Hirschman 1970). According to Hirschman, actors within an organisation face two choices when they perceive that the organisation is no longer serving their interests and their loyalty to the organisation reduces: they can "exit" or, if they stay, "voice" their disapproval. Under the AHMU, Hungary's threat of exit proved a potent tool, which allowed them to a certain degree, to "capture" the workings of the AHMU in such a way as to ensure that they exercised a disproportionate amount of power within the Austro-Hungarian National Bank. (2) The ability of a small-country player to co-opt such an institution points to a broader set of concerns about the game theoretic interaction of nations within a monetary union, including their asymmetric ability to exert power and influence over the terms of the supranational agreement. Institutional arrangements need to be designed to mitigate such concerns, and to prevent the ability of nations to undue (and disproportionate) influence over the workings of a monetary union, lest such actions lead to resentments, inefficient outcomes, or exits from the organisation.

The lessons that may be drawn from the AHMU, therefore, are that, even if there exist developed institutions of collaboration between the two units, there needs to be safeguards against the possibility of moral blackmail (through threats of exit) from the smaller entity. Had the First World War not intervened, the AHMU might have developed along these lines.

\section{The European monetary union (EMU)}

The 1957 Treaty of Rome, which established the European Economic Community (EEC), through the creation of a customs union and other measures allowed for a common market of goods, workers, and capital as well as for the determining of common transport and agricultural policies. Although this is often interpreted as a defeat for European federalism, in practice it laid the basis for the future development of a kind of economic federalism. In the terms of European integration theory, this phase was characterised by what would later became known as 'intergovernmentalism' 
although the idea was already present in the International Relations theory of 'realism' applied to European integration by Stanley Hoffman (1966) rather than the 'supranationalism' that neo-functionalists such as Ernst Haas had thought would come about (Haas 1958). Nevertheless, during the De Gaulle years (1958-1969 - the period studied by Hoffman in his famous 1966 article), while it is true that European integration slowed down and became primarily intergovernmental, it did not completely cease.

Integration gathered momentum again with the election of the centrist and proEuropean Valéry Giscard d'Estaing to the French Presidency in 1974. He and German Chancellor Helmut Schmidt renewed the Franco-German axis and oriented the integration process in a more political direction. The context within which this took place was the new situation of the world economy brought about by the collapse of the Bretton Woods Agreement, the crisis of Keynesian economy policy, the rise of neoliberalism and the new phase of globalisation that resulted from these developments. It was evident to many that individual European nation-states, even those with strong economies such as West Germany, were disadvantaged when acting alone faced with the powerful economic blocs emerging around the United States and Japan. For this reason, in 1983, the European Roundtable of Industrialists, concerned with the loss of European competitiveness called for the 'relaunch' of Europe. In1984, the European Parliament adopted a report by the European federalist Altiero Spinelli as a Draft Treaty Establishing the European Union. Although the member states quickly buried the plan, it further enhanced the drive towards greater integration. It also assisted Jacques Delors, who had been appointed President of the European Commission in the same year. It was under Delors that the European Commission launched an explicit programme to achieve monetary and economic union in a number of stages:

\section{Stage 1: 1 July 1990-31 December 1993}

1 July 1990: complete liberalisation of capital movements through the abolition of exchange controls in the EEC.

1992: Treaty of Maastricht adopts the completion of the EMU as a formal objective and the Treaty enters into force on 1 November 1993.

Maastricht established 'convergence criteria' on inflation, public finances (debt), interest rates and exchange rate stability.

Stage 2: 1 January 1994 to 31 December 1998

The European Monetary Institute established as the forerunner of the ECB which comes into existence in June 1998.

1995: the name 'Euro' is adopted for the new currency.

June 1997: the European Council adopts the Stability and Growth Pact (SGP) to ensure budgetary discipline of the new currency.

May 1998: the first eleven initial countries to participate in the Euro are selected.

Stage 3: 1 January 1999 to the present

1 January 1999: the Euro becomes a real currency and the ECB establishes a single monetary policy for the Eurozone.

1 January 2002: Euro notes and coins are introduced.

More countries join: Greece (2001), Slovenia (2007), Cyprus and Malta (2008), Slovakia (2009), Estonia (2011), Latvia (2014), Lithuania (2015). 
In 2018, the Eurozone comprises 19 members with 7 EU members are committed to joining it eventually. Denmark has opted out and of course the UK is leaving the EU after the Brexit vote in June 2016. This will mean a vast single currency area comprising 26 countries. Six other countries - the micro-states of Andorra, Monaco, San Marino and Vatican City and Kosovo and Montenegro - use the Euro as their official currency, the first four having formal agreements with the EU to do so and the last two unilaterally.

\section{Brexit and European integration}

Although it often has frictions with the EU, the UK, as the second-largest economic entity in the EU, a nuclear power, and permanent member of the United Nations Security Council, has been known as part of the EU troika along with France and Germany. Its role is irreplaceable, particularly in EU diplomacy and defence policies. With Brexit, the EU, as an important international actor, will inevitably see its role and influences decline.

Despite the fact that the UK does not use the Euro, Brexit will have important implications for the EMU's future. The UK's significant financial sector and the loss of its budgetary contributions will lead to numerous EU reforms in the wake of its exit. The EU should take advantage of this. Encouraging the adoption of the Euro by current euro-outs is a step in the right direction. While financial sector reforms are inevitable, the EU should be mindful of the benefits that London's financial markets have provided in the past and not make Brexit unnecessarily disruptive. Finally, the EU should use post-Brexit reforms as an opportunity to strengthen the Eurozone and make it more robust against future crises.

There was something remarkable about the recent rapid progress of European integration if one compares it with the period of 'Eurosclerosis' of the 1960s and early 1970s. We have progressed from a situation where the European regime was little more than an advanced 'international regime' marked by 'intergovernmentalism' to one where many of the elements of a true European federation are now in place. In 2015, we have a single market which includes all 28 member states, a single currency which is used by the majority of member states and will eventually be used by all but two, a European Central Bank, and a single monetary policy. Furthermore, the drive towards the completion of the single market and EMU has brought in their wake a strengthening of European institutions. The European Commission has played a key role in all of these developments and there has been a strengthening of the European Parliament as the co-decision maker with the European Council. Furthermore, the European Council itself, while representing 'national interests' has increasingly adopted not a simple 'national' perspective but a truly European one or at least one in which 'national' interest is increasingly defined in European terms. This simply reflects the realities of national governments in a complex, interdependent and globalised world. The EU has developed a set of institutional mechanisms which both give expression to this complexity but also allow the member states to retain a certain degree of autonomy. Besides the supposed strengthening of EMU and the institutional developments that have accompanied it, the process has also led to increasing the number of policy areas that now fall within the competences of the EU. Examples include education, the environment, social policy etc. 


\section{The Eurozone crisis}

When almost ten years of relative ease for the EMU's single currency came to an abrupt end with the start of the Greek debt crisis in 2010, the debate over the Euro's sustainability quickly turned to the question of whether there can be a monetary union without some sort of fiscal union. According to Harold James, Europe's financial crisis cannot be blamed on the Euro. The current crisis goes deeper, to a series of problems that were debated but not resolved at the time of the Euro's creation (James 2012).

The origins of the Eurozone crisis are explained in an informative study of the Committee of Central Bank Governors, which became the ECB. The book follows the process from preparation to execution of the concept of European monetary union and a common currency. It helps to understand the European monetary crisis in depth, by tracing behind-the-scenes negotiations. It was the constant tension between politicians and technocrats that shaped the Euro (James 2012).

Drawing on newly available archives from the Committee of Central Bank Governors and the Delors Committee of 1988-89, James shows that although the EMU has grown and evolved, the lack of coordination in policymaking, complex decision making, and the sheer number of interrelationships between monetary and economic variables have led to serious problems. The EMU was originally seen as another stepping stone to a politically unified Europe. Yet with the fall of the Berlin Wall, the disintegration of the Soviet Union, and the unification of Germany, the need for European political union as a means to ensure peace in Europe has largely disappeared. Given fading desire for full political union, the Euro project has lost the prospect of a stable platform in the foreseeable future (James 2012).

From the outset the Euro was a controversial construct. Design flaws in the Eurozone were well known from its inception-including a lack of fiscal union and no mechanisms to deal with asymmetric shocks and diverging competitiveness. However, political imperatives trumped economic concerns in the creation of a united states of Europe, and the Euro was the showpiece of this political project. The constant media reports of the EMU's immediate demise continue unabated, and there are no quick fixes to this complex situation. (James 2012).

This historical progression of economic and political integration has often been described in 'neo-functionalist' terms. The theory was originally associated with Haas (Haas 1958), but Haas coined the term to describe and explain the actual practices of figures such as Jean Monnet in the 1950s. By the 1960s, perhaps influenced by the neorealist critique of Hoffman (Hoffman 1966) but also by the Euro-pessimism of the de Gaulle period, Haas declared that the neo-functionalists had been mistaken (Haas 1958). Neo-functionalism, however, experienced a come-back in the 1990s as a result of the accelerated integration (Rosamond 2005). Such neo-functionalist accounts of European integration have sometimes been applied to the EMU and, especially, the Euro. Certainly leading up to the introduction of the Euro, there was an expectation that monetary union would 'spill-over' into greater fiscal and economic union. In 1991, the German Chancellor Helmut Kohl argued in favour of such a process that 'It is absurd to expect in the long run that you can maintain economic and monetary union without political union' (Kohl 1991), while British Chancellor Nigel Lawson, arguing in opposition to it, claimed that the EMU implied 'nothing less than European government... and political union, the United States of Europe'(Lawson 1989). These analyses 
need to be subjected to detailed empirical examination. It is likely that the actual processes of economic, monetary and political integration actually became dissociated from each other and were much more 'messy' than the neat neo-functionalist paradigm of 'spill-overs' would suggest (Hodson and Quaglia 2009).

In particular, this threw into question whether the criteria for entry into the Euro, which had been established at Maastricht, were applied sufficiently in certain cases, especially in relation to Greece. Furthermore, even major players such as France and Germany had failed to play by the rules that had been laid down, thus weakening the case for their application to the economically weaker states on the periphery (Greece, Ireland, Italy, Portugal and Spain). When the crisis broke, there was even talk of the collapse of the Euro or at least whether countries such as Greece would be forced out. This leaves an important question as to whether the EU can survive as a system with two or more distinctive fiscal policy regimes (i.e. the Eurozone + the UK and Denmark) or whether the non-Euro states should really leave the Union.

\section{The EMU and responses to the crisis}

In response to the crisis, the EU pushed through a number of measures, including the Treaty on Stability, Coordination and Governance in the Economic and Monetary Union (TSCG), better known as the "Fiscal Compact", which was signed by all EU leaders except those from the United Kingdom and the Czech Republic, and represented an important attempt to deal with some of the problems thrown up by the Eurozone crisis.

The European Commission published a communication in November 2012 entitled A blueprint for a deep and genuine economic union: launching a European debate (European Comission 2012). This began by emphasising the benefits of EMU and the creation of the single currency: the Euro is the world's second largest reserve currency; it has helped open up the internal market to more than 330 million citizens living in the Eurozone; it enables immediate price comparisons across countries; it has eliminated exchange rate risk and foreign transaction costs; it has facilitated a more efficient distribution of resources; and it has become a powerful tool for growth.

At the same time, the Commission recognised some of the weaknesses of the initial design of the EMU and the failure of states to adhere to the rules of the Stability and Growth Pact (SGP): some Eurozone states had accumulated large private and public debts; there were losses in competitiveness; and macro-economic imbalances. When the 2008 crisis struck there were considerable contagion effects and the crisis turned into a sovereign debt crisis. The Commission noted in particular that there was "the lack of a tool to address systematically macroeconomic imbalances". (European Comission 2012). The communication identified the following issues both before and since 2008:

(i) The SGP was insufficiently observed by the Member States and lacked robust mechanisms to ensure sustainable public finances. The Member States did not use periods of steady growth to pursue ambitious fiscal policies.

(ii) There was a reliance on "soft instruments" - peer pressure and recommendations which had limited impact on the Member States. 
(iii) There was a moral hazard problem as expanding global financial markets in the late 1990s provided a money supply which seemed to diminish risks.

(iv) There was a sharp increase in financial integration at the European level but, after 2008, a nationally segmented financial stability architecture. This led to inadequate coordination at all stages of the crisis.

The European Commission has played a key role in preserving the single market against emerging protectionist tendencies and fragmentation. It advanced a European Economy Recovery Programme with a series of legislative proposals which the European Parliament endorsed. In December 2011, these proposals became known as the "six-pack": three Regulations strengthening the SGP; two Regulations introducing a new budgetary surveillance measure; and one Directive imposing minimum standards for national budgets. Furthermore, the Commission advocated that the Treaty on Stability, Coordination and Governance (TSGC) be incorporated into EU law within five years and had already been working with the Parliament and the Council to integrate some of its elements into EU law applicable to Eurozone Member States. Next, the Commission introduced the "two-pack" which consists of two Regulations to reinforce both budgetary coordination and budgetary surveillance and aims at more targeted prevention and corrective action in cases of deviation from SGP budgetary requirements. This means the creation of a Single Supervisory Mechanism (SSM). In other words, it moved from "soft" instruments to more "hard" legal instruments.

These measures have taken shape with the introduction of new institutional instruments:

- Macroeconomic Imbalances Procedure (MIP), which is a system of surveillance to identify imbalances.

- A new Excessive Imbalance Procedure (EIP), which is a system of intervention to correct these imbalances.

- The European Semester, which means that surveillance of national budgets takes place across all Eurozone states in the first six months of the calendar year and the Commission provides policy advice to the states before they finalise their draft budgets for the following year.

- The European Stability Mechanism (ESM) inaugurated in October 2012.

One additional measure deserves to be highlighted: the creation of a Banking Union in order to end the disintegration of the EU's financial market and in order to further the completion of the EMU.

The European Commission provided a blueprint outlining a number of stages to complete the EMU:

- In the short term (6-18 months): full deployment of the new economic governance tools - the six-pack, the two-pack and the SSM - these do not require Treaty changes.

- In the medium term (18 months to 5 years): further budgetary coordination; deeper policy coordination in the field of taxation and employment; creation of a proper fiscal capacity for the EMU. Some of these measures will require Treaty amendments. 
- In the long term (beyond 5 years): progressive pooling of sovereignty and responsibility for solidarity competences to the EU level; a deeply integrated economic and fiscal governance framework to allow a common issuance of public debt; perhaps introducing Stability Bonds on a Euro-wide level.

The communication also pointed out that these developments imply a political union and reinforced democratic legitimacy and accountability.

In June 2012, Herman Van Rompuy, the President of the European Council, having consulted the President of the Commission and the President of the Parliament, prepared a report entitled Towards a Genuine Economic and Monetary Union that put forward a comprehensive vision of greater fiscal and economic union, including an SSM, an increased degree of common decisionmaking on national budgets, and a number of other measures for the absorption of country-specific shocks (Van Rompuy 2012). In its meeting in December 2012, the European Council endorsed these moves, stating that it "Agreed on a roadmap for the completion of the Economic and Monetary Union, based on deeper integration and reinforced solidarity. This process will begin with the completion, strengthening and implementation of the new enhanced economic governance, as well as the adoption of the Single Supervisory Mechanism and of the new rules on recovery and resolution and on deposit guarantees. This will be completed by establishment of a single resolution mechanism" (European Council 2012).

The Five Presidents report summarizes the debate on the Deep and Genuine Economic and Monetary Union (Juncker 2015). The debate was launched through the publication of the European Commission's Communication on 'A Blueprint for a Deep and Genuine EMU' in November 2012 (European Comission 2012). In comparison with the 2012 Communication, the Five Presidents report is less ambitious because it does not contain a proposal of debt mutualisation presented in the 2012 Blueprint. It would further undermine fiscal discipline on national level, already compromised by several bail-outs of the troubled countries and continuous breaching of fiscal criteria established by the Treaty on Functioning of the European Union (TFEU) and the Stability and Growth Pact (SGP).

All measures, which were to be adopted in the Stage 1 (between July 1, 2015 and June 30, 2017) as 'Immediate Steps', did not require changes in the EU Treaties. They were implemented through either EU secondary legislation or the Commission's own decisions. This cannot be said about the Stage 2 ('Completing the EMU Architecture') that will require changes in the Treaties although the time horizon proposed (until 2025) makes this potentially feasible (if accepted by all EU member states).

The Five President's Report anticipated the Eurozone having a treasury, with tax and debt-raising powers and powers to spend. Such a treasury function would clearly require political oversight. And indeed there is now an on-going discussion about the establishment of democratic accountability mechanisms within the Eurozone. The role of the ECB is of relevance in this discussion. 


\section{EMU governance and ECB accountability}

If mutualisation of at least a part of member states' debt issuance were to happen, the Eurozone would be taking a big stride towards a large, liquid, integrated bond market like that of the United States, which makes the Dollar such an attractive key currency. As such, it would partly address the complaint that the Euro is a currency without a state and so by definition lacks the independent fiscal capacity that is a fundamental characteristic of a reserve currency (Eichengreen and Wyplosz 2016).

The ECB, in fact, is the least accountable central bank among advanced nations (Werner 2006). There is no democratic accountability when the ECB strong-arms governments into policy actions that go well beyond any reasonable interpretation of its mandate. Not only is the ECB shielded from politicians, ECB statutes have also placed it beyond the reach of democratic rules on bad behaviour. The ultimate control politicians have over a central bank is the power to change its statutes and the power to appoint governors. For example, in the case of Germany, a simple majority in the Bundestag can change Bundesbank law. This procedure is absent in the Eurozone. The statutes of the ECB can only be changed by revising the Maastricht Treaty, which requires unanimity of all member states. The ECB today argues that the only institution that has the right to limit its power is the European Court of Justice, which has an activist Europhile interpretation of European treaties. The crisis has given the ECB governing council such an increased power that no national government or national institution can match it.

The project of European integration was not designed democratically, or at least not in the way democracy is traditionally conceived in terms of placing ultimate lawmaking authority in the hands of the people or their elected representatives. It is not even meant to be democratically responsive in the way that term is usually understood. Any democratic deficit that the EU suffers seems to many observers a deliberately constructed one. So how could we control the ECB in the future? It needs to be placed under a stricter and more direct supervision by democratically elected politicians. One of the institutions the president of the ECB puts himself in front of, the European Parliament, does not inspire anyone to believe that the ECB is being held accountable. This very independence means that democratic governments now have no way to keep the ECB accountable if it starts to violate its mandate (Feldstein 2012).

With almost prophetic insight German economist and former president of the Bundesbank Karl Otto Pöhl wrote in 1988: "In a monetary union with irreversibly fixed exchange rates the weak would become ever weaker and the strong ever stronger. We would thus experience great tensions in the real economy of Europe ... In order to create a European currency, the governments and parliaments of Europe would have to be prepared to transfer sovereign rights to a supranational institution" (James 2012).

The ECB has become more powerful than the Fed, but with even less democratic oversight. In the early stages of the Eurozone crisis, the ECB exercised its influence through secret letters to troubled member states such as Ireland and Italy, laying down conditions and implicitly threatening to withdraw support if they were not met. Now, the bank exercises its power directly and in public (James 2012).

The EC B is at a crossroads. Its original mandate was to be an independent technocratic institution, the legitimacy and credibility of which was set in terms of meeting its price stability mandate - output legitimacy. However, from the outbreak of 
the sovereign debt crisis, ECB unconventional monetary policies had a significant impact upon the direction of Eurozone member state macro-economic policies - and in a manner that contradicted the ECB's terms of delegation as outlined in the Maastricht Treaty, thus also undermining its input legitimacy. In light of the political salience of these policies and their impact, it is questionable whether the independence of the ECB remains democratically viable. ECB policy-making has become problematically controversial and politicized. At the very least, the reinforcement of European parliamentary scrutiny over ECB policy making is more urgent than ever (Högenauer and Howarth 2016).

\section{Historical lessons for the EMU}

Luca Einaudi has warned that comparisons between earlier monetary unions and the EMU are "misleading to some extent", since "technical aspects of money and political background have changed radically" (Einaudi 2000). Unlike in the nineteenth-century, we are now in a world of fiat currencies, of tighter European political and institutional integration, and of a vastly different system of national central banks. Despite this, a few lessons can be gleaned for the contemporary EMU, in light of the memory of the LMU, the SMU, and the AHMU:

(1) The fragility of monetary unions. One lesson from the historical record on monetary unions is recognition of the fragility of such arrangements, especially in the absence of other levers for fostering economic convergence and formal coordination of member states' economies. The LMU, the SMU, and the AHMU all disappeared, for various reasons, often having to do with a lack of coordination or too difficult financial circumstances, especially during the First World War.

(2) The importance of economic convergence for viable monetary union. Another lesson from the historical record is the issue of economic convergence and whether an Optimal Currency Area is an essential condition. But also whether this should be a "strong" OCA or a "weak" OCA as these terms were defined above. The SMU provides, perhaps, the most potent example of this factor, considering the Scandinavian nations' lack of economic convergence throughout their experience of monetary union. This helped to put pressures on the SMU, which eventually aided in its dissolution. Ceteris paribus economic convergence is an important element in a well-functioning monetary union. On the other hand, the United States is an example of an OCA which was weak but which, despite the Civil War and the currency collapse in the 1920s, has become a robust single currency. What is perhaps remarkable about the Euro is that, despite the great divergence across the EU's economies, it was first of all established and, second, has actually survived the most serious threat to its existence with the 2008 financial crisis. This suggests that certain key conditions have changed, particularly those dealt with under (3) below.

(3) The importance of institutional safeguards to curb moral hazard and to ensure deeper coordination. Another difficulty in monetary unions, highlighted by the examples of the LMU and the SMU, in particular, is that of moral hazard. It is important that monetary unions create institutional safeguards to prevent moral 
hazard and free-riding problems. Furthermore, the continuing existence of national interests in previous unions meant that it was difficult to coordinate fiscal and economic policies across the member states.

(4) The relevance of "national" interests. An important lesson, however, may be drawn in the comparison between the nineteenth century and the late twentieth and early twenty-first centuries: this is the changing role of the nation-state and of national governments. The early period was actually the heyday of nation-state nationalism, but this had considerably diminished by the last quarter of the twentieth century. The drive towards EMU was possible only because the EU's Member States were willing to surrender certain aspects of sovereignty to the supranational institutions. The EMU became, therefore, a much more deeply integrated Union than was possible, at least across different countries in the earlier period. In fact, it was only possible in a federation such as the United States or Canada because there was a willingness to create a new overarching entity. Although the EU is not yet a federation, it is developing into something quite similar. This has been borne out by the progress made in devising institutional responses to the crisis and the willingness to use it as a means of deepening integration even further.

(5) Finally, there is the challenge of creating representative and strong centralised institutions in a monetary union. Such institutions ought to be both (a) representative and (b) able to battle issues of moral hazard. The experience of the AHMU, in which Hungary was able to extort highly favourable terms through threat of exit, points to the importance of political institutions in the creation of any tenable monetary union. The current arrangement of the ECB, in fact, seems poorly suited to this task at hand, in part because of precisely the sort of misalignment of power seen in the AHMU. ${ }^{1}$

\section{Conclusion}

There is an urgent need for the Eurozone to address their problems such as the Greek debt restructuring process as a matter of urgency or it could be a destabilising factor in the international currency system. The Eurogroup failed to implement a definitive solution to the Greek debt problem. This is yet more evidence that the current institutional structure of the Eurozone/EU is unable to deal with the scale of economic problems caused by an incomplete monetary union.

Nevertheless, EMU is different from the earlier experiences with monetary unification that we have described in the three case studies above. It has created a single

\footnotetext{
${ }^{1}$ At present, the ECB, headquartered in Frankfurt, has a system of voting rights that is grossly unrepresentative. Proposed reforms to the system, while somewhat helpful in closing the gap between large and small nations, introduce a curious system of rotation that will likely prove controversial to wealthy creditor nations, especially Germany. The exclusion of Jens Weidmann, the president of the Deutsche Bundesbank, from voting every fifth month will likely sit uneasily with Germans, considering both that the nation represents $30 \%$ of Eurozone GDP and its crucial role in extending credit to PIIGS nations. The creation of a more representative system for governing the Eurozone is a sine qua non for the EU, an institution that has continually been dogged by criticisms of its "democratic deficit". "Voting Rights at the ECB: New Club Rules" in The Economist (12-20 December 2013), 72-5
} 
currency, the Euro, and a common monetary authority, the ECB. No one can predict with certainty which way this crisis will turn from here. There are no precedents for the challenges Europe faces. Historical experiences of currency crises are not really applicable because the Eurozone is an unprecedented construct. However, the European Commission, the European Parliament and the European Council have, in fact, embarked on an ambitious programme not just to keep the single currency afloat but to develop a set of institutional mechanisms that are designed to remedy some of the weaknesses of the original design.

This on-going uncertainty limits Eurozone reform and renewed tensions with France and countries like Greece who may be forced to exit the Euro. There is also a possibility of a hard Brexit because of benign neglect on behalf of the EU and the incapability of the UK to engage constructively because of internal divisions within the governing conservative party.

The Eurozone, in its relatively short time of existence, has successfully overcome a number of crisis periods. As the political landscape is changing, it will be difficult to develop more constructive and proactive solutions for the Eurozone crisis, such as debt restructuring, than was the case with the 'muddling-through' approach that has characterised the Eurozone crisis strategy in the last few years, especially in Greece. The ECB epitomizes that perceived 'democratic deficit' run by an unaccountable bureaucracy that poses serious problems for the future of the Eurozone.

Open Access This article is distributed under the terms of the Creative Commons Attribution 4.0 International License (http://creativecommons.org/licenses/by/4.0/), which permits unrestricted use, distribution, and reproduction in any medium, provided you give appropriate credit to the original author(s) and the source, provide a link to the Creative Commons license, and indicate if changes were made.

\section{References}

Bordo MD (1992) Bimetallism. In Peter K. Newman, Murray Milgate and John Eatwell. (eds.), The new palgrave encyclopedia of money and finance

De Cecco M (1992) European monetary and financial cooperation before the first world war. Rivista di Storia Economica 9:55-76

Deo S, Donovan P, Hatheway L (2011) A brief history of break-ups, UBS investment research, global economic perspectives, 11 October. Available at www.ubs.com/economics

Donovan P, Hatheway L, Deo S, Constable S (2010) 'A brief history of break-ups', UBS investment research global economic perspectives, 24 February. Available at www.ubs.com/economics

Economist Voting Rights at the ECB: New club rules in (12-20 December 2013), 72-5

Eichengreen B, Wyplosz C (2016) Minimal conditions for the survival of the euro, Voxeuorg, 14 March

Einaudi L (2000) From the franc to the 'Europe': the attempted transformation of the Latin monetary union into a European monetary union, 1865-1873. Econ Hist Rev 53(2/2000): 284-308

Einaudi L (2001) Money and politics: European monetary unification and the international gold standard (1865-1873). Oxford University Press, Oxford

European Comission (2012) A blueprint for a deep and genuine economic and monetary union: launching a European debate. In: Brussels: COM (2012) 777 final/2

European Council (2012) Conclusions. European council meeting Brussels: EUCO 205/12

Feldstein M (2012) The failure of the Euro: the little currency that couldn't," Foreign Affairs 911, January/ February, 2012

Flandreau M (2006) 'The logic of compromise: monetary bargaining in Austria-Hungary 1867-1913', discussion paper no. In: 5397, December. Centre for Economic Policy Research, London

Haas EB (1958) The uniting of Europe. Stanford Univ. Press, Stanford 
Hirschman AO (1970) Exit, voice, and loyalty: responses to decline in firms, organizations, and states. Harvard University Press, Cambridge, MA

Hodson D, Quaglia L (2009) European perspectives on the global financial crisis: introduction. J Common Mark Stud 47(5):939-953

Hoffman S (1966) Obstinate or Obsolete? The fate of the nation-state and the case of Western Europe. Daedulus 95(3):862-915

Högenauer AL, Howarth D (2016) Unconventional monetary policies and the European Central Bank's problematic democratic legitimacy. J Public Law/Zeitschrift für öffentliches Recht 71(2):425-448

James H (2012) Making the European monetary union. Belknap Press, Cambridge, Massachusetts

Juncker JC (2015) Five presidents report: completing Europe's economic and monetary union: report by: JeanClaude Juncker in close cooperation with Donald Tusk, Jeroen Dijsselbloem, Mario Draghi and Martin Schulz (Brussels: European Commission), 22 June 2015

Kohl H (1991) Speech, Bundestag, 6 November 1991

Lawson N (1989) Speech to the Royal Institute for international affairs, Chatham House, 25 January 1989

Loughlin J, Ryan J (2014) Historical monetary unions. Lessons for the current Eurozone crisis?, Studia Diplomatica, vol. LXVII, issue 4: Various shades of federalism: Which responses to the rise of populism and euroscepticism?

Rosamond B (2005) The uniting of Europe and the foundation of EU studies: revisiting the neofunctionalism of Ernst B. Haas. J Eur Publ Policy 12(2):237-254

Van Rompuy H (2012) Towards a genuine economic and monetary union. Report by the President of the European Council, Brussels: EUCO 120/12, June

Vanthoor, WFV (1996) European monetary union since 1848: A political and historical analysis (Cheltenham, 1996)

Werner RA (2006) A comparative analysis of the independence of the ECB, the Bundesbank and the Reichsbank. Int Financ Rev 6:1-16 